\title{
PERAN KONSELING, PENGAWASAN, DAN PEMERIKSAAN OLEH PETUGAS PAJAK DALAM MENDORONG KEPATUHAN WAJIB PAJAKDAN DAMPAKNYA TERHADAP PENERIMAAN NEGARA
}

\author{
Amilin \\ Fakultas Ekonomi dan Bisnis UIN Syarif Hidayatullah Jakarta \\ E-mail: amilin@uinjkt.ac.id
}

\begin{abstract}
The purposes of this study to analyze the influence of counselling, supervision, and the tax examination, on the tax compliance and it's impact on country revenue.The population of this research is Corporate Taxpayers. Primary data used in this study collected by the questionnaire in Jakarta Area. Convenience sampling method used in this study. There are any 197 from 200 questionnaires are feasible to analyzed. The Structural Equation Modeling (SEM) used to test the hyphotesis. The result of this study showed that the variable of counselling and variable of the tax examination positively influence on the tax compliance, while the supervision variable have no effect.Other findings that variable of tax compliance can mediate the influence of counselling, supervision, tax examination variebles on country revenue.
\end{abstract}

Keywords:counselling, supervision, examination, tax compliance, country revenue

\begin{abstract}
Abstrak: Penelitian inibertujuan untuk memperoleh bukti empiris tentang pengaruh konseling, pengawasan, dan pemeriksaan pajak terhadap kepatuhan wajib pajak dalam memenuhi kewajiban perpajakannya dan dampaknya terhadap penerimaan negara. Populasi dalam penelitian ini adalah para Wajib Pajak yang ada di wilayah Jakarta. Metode pemilihan sampel menggunakan metode convenience sampling.Pengumpulan data menggunakan kuesioner. Responden penelitian ini berjumlah 200wajib pajak dan yang layak untuk diuji sebanyak 197 kuesioner. Pengujian hopotesis menggunakan Structural Equation Modeling (SEM). Hasil penelitian ini menunjukkan bahwa kegiatan konseling dan pemeriksaan pajak berpengaruh positif dan signifikan terhadap kepatuhan wajib pajak dalam memenuhi kewajiban perpajakannya, sedangkan pengawasan tidak memberikan dampak yang signifikan terhadap kepatuhan wajib pajak. Temuan lainnya, kepatuhan wajib pajak dapat memediasi pengaruh parsial variabel konseling, pengawasan, dan pemeriksaan terhadap penerimaan negara.
\end{abstract}

Kata Kunci: konseling, pengawasan, pemeriksaan, kepatuhan pajak, penerimaan negara

\section{PENDAHULUAN}

Pajak merupakan elemen penting dalam mengelola pendapatan sebuah negara (Lymer \& Oats, 2009). Diskusi tentang pendapatan negara dari sektor pajak tidak dapat dipisahkan dari kepatuhan wajib pajak dalam memenuhi kewajiban perpajakannya. Literatur tentang kepatuhan pajak meliputi beberapa disiplin ilmu termasuk Bidang Ekonomi dan Psikologi (Loo, McKerchar, Hansford, 2010). Berkenaan dengan ist4Wilah kepatuhan membayar pajak, ada beberapa ahli yang mendefinisikannya, dua diantaranya 
adalah Andreoni, Erard and Feinstein (1998) dan (Kirchler: 2007). Andreoni, Erard and Feinstein (1998) mendefinisikan kepatuhan membayar pajak sebagai kesediaan pembayar pajak dalam mematuhi hukum pajak untuk mendapatkan keseimbangan perekonomian suatu negara. Definisi secara sederhana menurut (Kirchler: 2007) yaitu kesediaan wajib pajak untuk membayar kewajiban pajaknya.

Penerimaan negara dari sektor pajak sangat penting untuk proses pembangunan nasional yang diharapkan dapat meningkatkan kemakmuran dan kesejahteraan rakyat. Kontribusi penerimaan pajak terhadap penerimaan negara diharapkan semakin meningkat dari tahun ke tahun (Priantara, 2010). Untuk lebih memaksimalkan penerimaan pajak, Pemerintah telah mengambil langkah-langkah kebijakan agar dapat mendorong kesadaran masyarakat untuk mau membayar pajak. Sebelum membuat kebijakan-kebijakan tersebut, Pemerintah perlu mengidentifikasi faktor-faktor yang dapat mempengaruhi penerimaan pajak.

Tugas Direktorat Jenderal Pajak yaitu melakukan pembinaan, penelitian, pengawasan, dan pelayanan dalam hubungan dengan pelaksanaan pemenuhan kewajiban perpajakan dari wajib pajak, sesuai dengan ketentuan yang diatur dalam Peraturan Perundang-undangan Perpajakan yang berlaku. Kegiatan konseling pajak merupakan salah satu bentuk kegiatan pembinaan yang dilakukan oleh Direktorat Jenderal Pajak terhadap wajib pajak. Konseling Pajak menjadi sarana yang disediakan bagi Wajib Pajak untuk melakukan klarifikasi terhadap data yang tercantum dalam Surat Himbauan. Konseling merupakan salah bentuk untuk meningkatkan kepatuhan Wajib Pajak secara sukarela, dengan tujuan untuk mewujudkan transparansi proses pemanfaatan data Wajib Pajak dengan landasan Perdirjen Pajak Nomor 170/PJ/2007.

Sebagai implementasi dari kegiatan pembinaan terhadap wajib pajak, selain kegiatan konseling, Pemerintah melalui Direktorat Jenderal Pajak perlu melakukan kegiatan pengawasan. Pengawasan sebagai salah satu tugas pokok Direktorat Jenderal Pajak pada dasarnya meliputi kegiatan penelitian dan pemeriksaan di bidang perpajakan dengan landasan Surat Edaran Ditjen Pajak Nomor SE-05/PJ.07/2004. Selain kegiatan konseling dan pengawasan, kegiatan pemeriksaan pajak juga merupakan bagian penting dalam upaya meningkatkan kepatuhan wajib pajak. Menurut Priantara (2010), pemeriksaan pajak merupakan instrumen yang baik untuk meningkatkan kepatuhan wajib pajak, baik formal maupun materil berdasarkan peraturan perpajakandengan tujuannya untuk menguji dan meningkatkan kepatuhan perpajakan para wajib pajak. Tata cara Pemeriksaan diatur dalam Peraturan Menteri Keuangan PMK Nomor 17/PMK.03/2013. Kepatuhan wajib pajak akan sangat berdampak baik secara langsung maupun tak langsung pada penerimaan pajak.

Peran serta wajib pajak dalam sistem pemungutan pajak sangat menentukan tercapainya rencana penerimaan pajak yang optimal dapat dilihat dari berimbangnya tingkat penerimaan pajak aktual dengan penerimaan pajak potensial (tidak terjadi tax gap). Penelitian terdahulu tentang kepatuhan pajak dilakukan oleh Handayani, et al. (2012), Kusbandiyah et al. (2013), Permadi (2013), Fahluzy, Fahmi dan Agustina (2014), Nugroho dan Zulaikha (2012), Agustina (2014), Widayati dan Nurlis (2010), Nugroho dan Zulaikha (2012), Setyonugroho dan Sarjono (2013). Sedangkan penelitian tentang penerimaan pajakdiantaranya telah dilakukan Rantung dan Adi (2009), Hardiningsih dan Yulianawati (2011), dan Norsain dan Abu Yasid (2013). Dari penelitian-penelitian tersebut belum ditemukan bukti empiris secara komprehensif yang menguji faktor pengawasan pajak, konseling pajak, dan pemeriksaan pajak terhadap kepatuhan wajib pajak dalam memenuhi kewajiban perpajakannya dan implikasinya terhadap penerimaan 
negara dari sektor pajak. Oleh karena itu, penelitian ini mencoba untuk melakukan pengujian secara komprehensiyang diharapkan menghasilkan penelitian yang berkualitas dalam memberikan kontribusi dan masukan kepada Pemerintah khususnya dalam membuat kebijakan di bidang perpajakan.

Seiring dengan semakin menurunnya peranan minyak dan gas bumi terhadap penerimaan negara, penelitian ini sangat penting dan perlu dilakukan karena diharapkan dapat memberi masukan, khususnya kepada Pemerintah dalam menggali potensi penerimaan pajak yang dapat digunakan untuk pembangunan bangsa. Oleh karena itu penelitian ini diberi judul: "Peran Konseling, Pengawasan, dan Pemeriksaan Pajak Dalam Mendorong Kepatuhan Wajib Pajak dan Dampaknya Terhadap Penerimaan Negara dari Sektor Pajak.” Topik ini sangat aktual, menarik dan mendesak untuk diteliti karena masalah pengawasan pajak, konsultasi pajak, dan pemeriksaan pajak dalam pelaksananaan di lapangan sudah secara reguler dilakukan oleh para aparatur pajak, namun demikian, sampai selesai disusunnya penelitian ini belum ditemukan hasil kajian empris secara komprehensif yang berdampak pada meningkatnya kepatuhan wajib pajak dalam melaksanakan kewajiban perpajaknnya.

Tujuan penelitian ini untuk memperoleh bukti empiris tentang pengaruh konseling, pengawasan, dan Pemeriksaan Pajak yang dilakukan oleh aparatur pajak terhadap kepatuhan wajib pajak dalam memenuhi kewajiban perpajakannya, serta dampaknya terhadap penerimaan negara dari sektor pajak. Hasil penelitian ini diharapkan dapat memberikan manfaat bagi pengembangan ilmu pengetahuan, aparatur pajak, konsultan pajak, wajib pajak serta perumusan kebijakan Pemerintah dalam bidang perpajakan. Pemerintah juga dapat melakukan evaluasi dan penyempurnaan dalam aspek strategi, teknik, dan metode pengawasan, konseling, dan pemeriksaan pajak yang benar-benar efektif dan efisien sehingga penerimaan negara meningkat secara signifikan seiring dengan meningkatnya kepatuhan para wajib pajak.

\section{KJIAN TEORI}

Teori Kemakmuran. Teori kemakmuran yang kemukakan oleh Adam Smith dalam Becker (2007: 17) menyatakan bahwa tingkat kemakmuran ditentukan oleh kemampuan manusia sebagai salah satu faktor produksi dalam sebuah negara. Manusia yang berakal dan berbudaya tentu menghendaki dalam kehidupannya ingin makmur dan sejahtera. Aplikasi teori kemakmuran dalam penelitian ini diterapkan dalam kontkeks pembangunan dimana kegiatan pembangunan merupakan tugas sebuah negara.

Konseling Pajak. Berdasarkan Peraturan Dirjen PajakNomor170/PJ/2007 tanggal 11 Desember 2007, Konseling Pajakadalahsarana yang disediakan bagi Wajib Pajak untuk melakukan klarifikasi terhadap data yang tercantum dalam Surat Himbauan. Konseling merupakan salah bentuk untuk meningkatkan penerimaan pajak, dengan tujuan untuk mewujudkan transparansi dalam proses pengawasan atas pemanfaatan data Wajib Pajak.

Pengawasan Pajak. Fungsi pengawasan sebagai salah satu tugas pokok Direktorat Jenderal Pajak pada dasarnya meliputi kegiatan penelitian di bidang perpajakan. Berdasarkan Surat Edaran Dirjen Pajak Nomor SE-05/PJ.07/2004 tan g gal 16 J un i 2004 salah satu bentuk pengawasan terhadap wajib pajak adalah aktivitas himbauan yaitu kegiatan persuasif yang dilakukan dengan cara mengirimkan surat untuk memberitahukan kondisi pelaksanaan kewajiban perpajakan bagiwajib pajak terpilih. 
Pemeriksaan Pajak. Pengertianpemeriksaan pajak menurut Undang-undang Nomor 28 Tahun 2007 Pasal 29 dan Peraturan Menteri Keuangan Nomor: 17/PMK.03/2013 tanggal 7 Januari 2013 yaitu serangkaian kegiatan menghimpun dan mengolah data, keterangan dan/atau bukti yang dilaksanakan secara objektif dan profesional berdasarkan suatu standar pemeriksaan untuk menguji kepatuhan pemenuhan kewajiban perpajakan dan/atau untuk tujuan lain dalam rangka melaksanakan ketentuan peraturan perundang-undangan perpajakan.

Kepatuhan Wajib Pajak. Kepatuhan pajak diharapkan lebih merujuk pada kepatuhan sukarela yaitu mencakup tingkatan kesadaran untuk tunduk kepada peraturan perpajakan yang berlaku tanpa disertai dengan aktivitas tindakan dari otoritas pajak, serta konsisten dalam menjalankan sesuatu yang tersirat dari aturan pajak tersebut (Devano dan Rahayu, 2005:56). Indikator kepatuhan pajak dalamera sistem self assessment didasarkan pada pemenuhan kewajiban Wajib Pajak untuk melaporkan semua penghasilan secara akurat kedalam Surat Pemberitahuan (SPT).

Penerimaan Negara. Penerimaan negara dapat diperoleh dari berbagai sumber. Konsep penerimaan negara dalam penelitian ini maksudnya adalah penerimaan negara yang khusus berasal dari sektor penerimaan pajak. Peranpajak sangat penting bagi kemandirian pembangunan, karena pajak merupakan salah satu sumber penerimaan negara dari dalam negeri yang paling utama selain dari minyak dan gas bumi untuk mengisi Anggaran Pendapatan dan Belanja Negara (Brotodiharjo,1998:38).

Kerangka Pemikiran dan Hipotesis Penelitian. Kerangka pemikiran berikut ini dengan dukungan beberapa hasil penelitian sebelumnya dijadikan dasar untuk merumuskan hipotesis penelitian ini. Handayani, et al. (2012) menyatakan bahwa kesadaran yang tinggi muncul karena adanya motivasi Wajib Pajak. Namun demikian, peran pengawasan oleh aparatur pajak dapat mendorong wajib pajak agar termotivasi dalam mematuhi kewajiban perpajakannya. Pendapat ini didukung oleh Kusbandiyah et al. (2013) dan Permadi (2013). Hasil penelitian Kusbandiyah et al. (2013) menunjukkan bukti bahwa pengawasan pajak dapat mendorong wajib pajak untuk mengisi SPT dengan tepat waktu. Sedangkan hasil penelitian Permadi (2013) menunjukkan bahwa Pengisian SPT merupakan salah satu indikator kepatuhan wajib pajak dalam memenuhi kewajiban perpajakannya. Melalui pengawasan oleh aparatur pajak, wajib pajak cenderung untuk mengisi dan melaporkan SPT dengan tepa waktu. Dari penjelasan di atas dapat disimpulkan bahwa pengawasan pajak dapat mendorong wajib pajak dalam mematuhi peraturan perpajakan.

Beberapa penelitian terdahulu yang dilakukan oleh Fahluzy, Fahmi dan Agustina (2014), Nugroho dan Zulaikha (2012), dan Agustina (2014) menunjukkan hasil yang konsisten. Penelitian yang dilakukan oleh Ortega et al. (2013) di Amerika Latin menunjukkan bukti empiris bahwa kegiatan konseling pajak dapat meningkatkan tingkat kepatuhan wajib pajak dalam memenuhi kewajiban perpajakannya. Hasil penelitian ini didukung oleh Nugroho dan Zulaikha (2012) yang memperoleh bukti empiris bahwa melalui konseling, wajib pajak mendapatkan informasi yang memadai tentang hak dan kewajiban wajib pajak. Dengan demikian, pemahaman wajib pajak melalui kegiatan konseling dapat meningkatkan kesadaran wajib pajak dalam mematuhi peraturan perpajakan. Hasil penelitian ini dikonfirmasi oleh Fahluzy, Fahmi dan Agustina (2014), yang menunjukkan bukti bahwa konseling memberikan kemudahan bagi wajib pajak 
dalam memperoleh informasi yang diperlukan sehingga dapat meningkatkan kepatuhan wajib pajak. Dari penjelasan di atas dapat disimpulkan bahwa konseling pajak dapat mendorong wajib pajak dalam mematuhi peraturan perpajakan.

Hasil penelitian Widayati dan Nurlis (2010) memperoleh bukti empiris bahwa pemeriksaan pajak dapat meningkatkan kepatuhan wajib pajak. Hasil penelitian ini didukung oleh penelitian Nugroho dan Zulaikha (2012) serta Setyonugroho dan Sarjono (2013) yang menunjukkan bukti bahwa pemeriksaan oleh auditor pajak dapat mendorong wajib pajak lebih berhati-hati dalam menghitung kewajiban perpajakannya dan melaporkan kewajiban perpajakannya dengan tepat waktu. Dari penjelasan di atas dapat disimpulkan bahwa pemeriksaan pajak dapat mendorong wajib pajak dalam kewajiban perpajakannya.

Beberapa penelitian terdahulu menunjukkan bukti empiris bahwa kepatuhan wajib pajak dapat meningkatkan penerimaan negara dari sektor pajak. Penelitian-penelitian tersebut diantaranya dilakukan oleh Rantung dan Adi (2009), Hardiningsih dan Yulianawati (2011), dan Norsain dan Abu Yasid (2013). Hasil penelitian Rantung dan Adi (2009) diperoleh bukti empiris bahwa kepatuhan wajib pajak melalui pengisian SPT dan membayar pajak tepat waktu dapat mendorong adanya peningkatan pendapatan negara. Hasil penelitian Hardiningsih dan Yulianawati (2011) menunjukkan bukti empiris bahwa meningkatnya sumber penerimaan negara salah satunya disebabkan karena para wajib pajak telah mematuhi aturan perpajakan yang berlaku. Sedangkan Norsain dan Abu Yasid (2013) mendorong agar Pemerintah dapat menjaga dengan baik kepatuhan wajib pajak karena melalui wajib pajak yang patuh inilah penerimaan negara dari sektor pajak menjadi meningkat. Dari penjelasan di atas dapat disimpulkan bahwa kepatuhan wajib pajak dalam memenuhi kewajiban perpajakannya dapat dapat meningkatkan penerimaan negara dari sektor pajak.

Berdasarkan uraian teoritis, hasil-hasil penelitian yang relevan, dan kerangka berfikir yang diuraikan pada bagian sebelumnya, maka dapat dirumuskan hipotesis penelitian sebagai berikut:

Ha1: Pengawasan pajak berpengaruh positif terhadap kepatuhan wajib pajak dalam memenuhi kewajiban perpajakannya.

Ha2: Konseling pajak berpengaruh positif terhadap kepatuhan wajib pajak dalam memenuhi kewajiban perpajakannya.

Ha3: Pemeriksaan pajak berpengaruh positif terhadap kepatuhan wajib pajak dalam memenuhi kewajiban perpajakannya.

Ha4: Kepatuhan wajib pajak berpengaruh positif terhadap penerimaan negara.

Ha5: Pengawasan pajak berpengaruh positif terhadap penerimaan negara melalui kepatuhan wajib pajak.

Ha6: Konseling pajak berpengaruh positif terhadap penerimaan negara melalui kepatuhan wajib pajak.

Ha7: Pemeriksaan pajak berpengaruh positif terhadap penerimaan negara melalui kepatuhan wajib pajak.

\section{METODE}

Populasi, Metode Pemilihan Sampel, dan Pengukuran Variabel. Penelitian ini merupakan jenis penelitian kausalitas pada populasi wajib pajak di Kantor Pelayanan Pajak Direktorat Jenderal Pajak Wilayah Jakarta yaitu KPP Setiabudi Satu, KPP Setiabudi 
Dua, KPP Setiabudi Tiga, KPP Tebet, dan KPP Mampang Prapatan, KPP Pasar Minggu, KPP Pancoran, KPP Cilandak. Responden penelitian ini adalah para Wajib Pajak Korporat. Metode pemilihan sampel menggunakan metode convenience sampling. Pengumpulan data lapangan menggunakan kuesioner dengan teknik personally administered questionnaires. Variabel Konseling Pajak terdiri dari 5 indikator pernyataan, variabel Pemeriksaan Pajak terdiri dari 5 indikator pernyataan, Variabel Pemeriksaan Pajak terdiri dari 15 indikator pernyataan, Variabel Kepatuhan Wajib Pajak terdiri dari 6 indikator pernyataan, dan Variabel Kepatuhan Wajib Pajak terdiri dari enam butir pernyataan. Skala pengukuran untuk semua variabel menggunakan skala Likert dengan nilai maksimum 5 dengan rentang nilai dari nilai sangat setuju (5) sampai dengan sangat tidak setuju (1).

Metode Analisis Data.Teknik analisis data menggunakan uji statistik deskriptif dan uji kualitas data. Pengujian statistik deskriptif terdiri dari: jumlah data (sum), data maksimum, data minimum, data rata-rata (mean), dan data deviasistandar. Pengujian kualitas data terdiri dari uji validitas dan reliabilitas data. Uji validitas dilakukan dengan membandingkan nilai $r_{\text {hitung dengan }} \mathrm{r}_{\text {tabel.Jika }} \mathrm{r}_{\text {hitung }}$ lebih besar dari $\mathrm{r}_{\text {tabel }}$ maka butir pertanyaan tersebut adalah valid, tetapi jika rhitung lebih kecil dari pada $\mathrm{r}_{\text {tabel }}$ maka butir pertanyaan tersebut tidak valid (Ghozali, 2011:53). Uji realibilitas data menggunakan metodeCronbach's Alpha. Nilai alpha bervariasi dari $0-1$, suatu pertanyaan dapat dikategorikan reliabel jika nilai alpha lebih besar dari 0,6 (Nunnaly (1967) dalam Ghozali (2011: 48)).Metode pengujian hipotesis menggunakan Structural Equation Modeling (SEM). Alat statistik untuk menguji hipotesis menggunakan Lisrel.

\section{HASIL DAN PEMBAHASAN}

Tingkat Pengembalian Kuesioner dan Profil Responden. Pengumpulan data menggunakan kuesioner terhadap Wajib Pajak di Wilayah Jakarta sebanyak 200 kuesioner. Seluruh kuesioner dapat kembali, dengan demikiantingkat pengembalian kuesioner sebesar 100\%. Data yang bisa diolah sebanyak 197 kuesioner (98,5\%). Pada Tabel 1 disajikan profil responden berdasarkan tingkat pendidikan. Dari data tersebut, mayoritas responden memiliki pendidikan Strata Satu.

Tabel 1. Profil Responden Berdasarkan Tingkat Pendidikan

\begin{tabular}{llrrrr}
\hline & & Frequency & Percent & Valid Percent & Cumulative Percent \\
\hline Valid & SLTA & 64 & 32.5 & 32.7 & 32.7 \\
& Diploma & 41 & 20.8 & 20.9 & 53.6 \\
& Strata 1 (S1) & 88 & 44.7 & 44.9 & 98.5 \\
& Strata 2 (S2) & 3 & 1.5 & 1.5 & 100.0 \\
& Total & 196 & 99.5 & 100.0 & \\
Missing & System & 1 & .5 & & \\
Total & & 197 & 100.0 & & \\
\hline
\end{tabular}

Sumber: Hasil pengolahan data

Hasil Uji Kualitas Data.Berikut penjelasan hasil uji validitas dan hasil uji reliabilitas data. Butir-butir pernyataan dinyatakan valid apabila nilai corrected item-total correlation lebih besar dari $\mathrm{r}_{\text {tabel}}(0,139)$. Semua indikator pada variabel konseling pajak(5 pernyataan) dinyatakan valid. Semua indikator pada variabel pengawasan pajak (5 pernyataan) 
dinyatakan valid. Semua indikator pada variabel pemeriksaan pajak (15 penyataan) dinyatakan valid. Pada variabel kepatuhan pajak, dari 4 indikator yang diuji, indikator pertama tidak valid. Pada variabel penerimaan negara, semua indikator (6 pernyataan) dinyatakan valid. Pada Tabel 2 disajikan hasil uji reliabilitas data. Berdasarkan tabel 2 dapat disimpulkan bahwa semua variabel dinyatakan reliable karena nilai Cronbach's Alpha lebih besar dari 0,6.

Tabel 2. Hasil Uji Reliabilitas Kuesioner

\begin{tabular}{lcc}
\hline \multicolumn{1}{c}{ Variabel } & Cronbach's Alpha & Keterangan \\
\hline Konseling Pajak & 0,699 & Reliabel \\
Pengawasan Pajak & 0,648 & Reliabel \\
Pemeriksaan pajak & 0,768 & Reliabel \\
Kepatuhan Pajak & 0,608 & Reliabel \\
Penerimaan Pajak & 0,622 & Reliabel \\
\hline
\end{tabular}

Sumber: Hasil pengolahan data

Hasil Uji Overall Mean Score.Pada Tabel 3 disajikan hasil perhitungan overall mean score. Dari tabel tersebut dapat diketahui bahwa secara umum variabel-variabel yang diuji memiliki mean score dengan katogori tinggi dan sangat tinggi.

Tabel 3. Tabel Overall Mean Score

\begin{tabular}{clccc}
\hline No & \multicolumn{1}{c}{ Variabel } & $\begin{array}{c}\text { Overall Mean } \\
\text { Score }\end{array}$ & Interval & Kategori \\
\hline 1 & Konseling Pajak & 4,11 & $3.41-4.20$ & Tinggi \\
2 & Pengawasan Pajak & 4,18 & $3.41-4.20$ & Tinggi \\
3 & Pemeriksaan Pajak & 4,05 & $3.41-4.20$ & Tinggi \\
4 & Kepatuhan Pajak & 3,96 & $3.41-4.20$ & Tinggi \\
5 & Penerimaan Negara & 4,33 & $4.21-5.00$ & Sangat tinggi \\
\hline Sumber: Hasil pengolahan data & &
\end{tabular}

Hasil Uji Kesesuaian Model.Berikut disajikan hasil pengolahan data dengan Lisrelpada masing-masing variabel. Hasil uji confirmatory factor analysis atasvariabel Konseling Pajak tersaji pada Gambar 1 berikut ini.

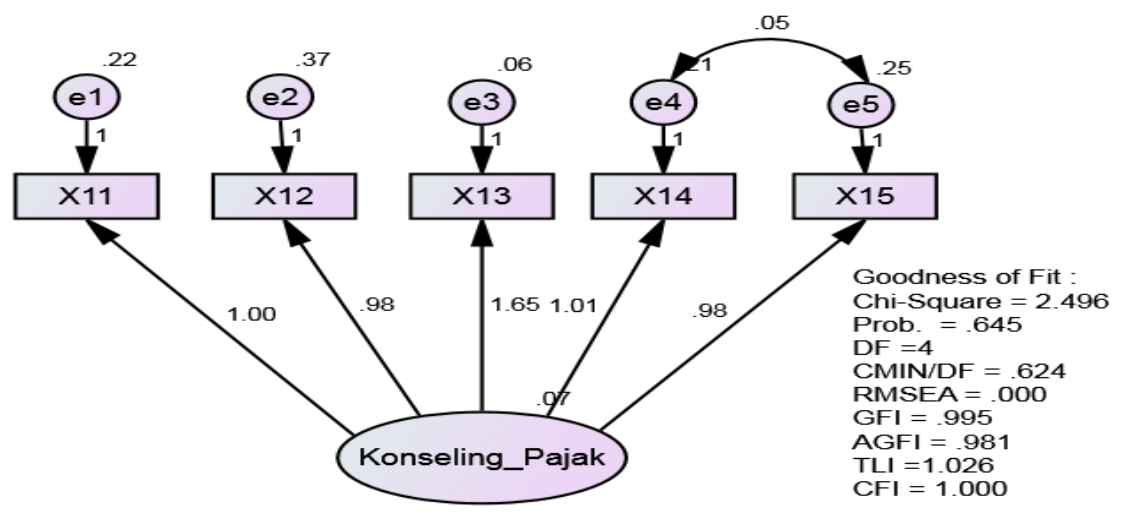

Gambar 1. Measurement ModelVariabel Konseling Pajak 
Hasil uji kesesuaian model menghasilkan tingkat penerimaan yang baik. Nilai chisquare sebesar 2.496 dengan 0,645 > 0,05 dan $\mathrm{df}=4$, danindeks GFI, AGFI, TLI, CLI, dan RMSEA berada dalam rentang nilai yang diharapkan. Selanjutnya, hasil uji confirmatory factor analysis atasvariabel Pengawasan Pajaktersaji pada Gambar2 berikut ini.

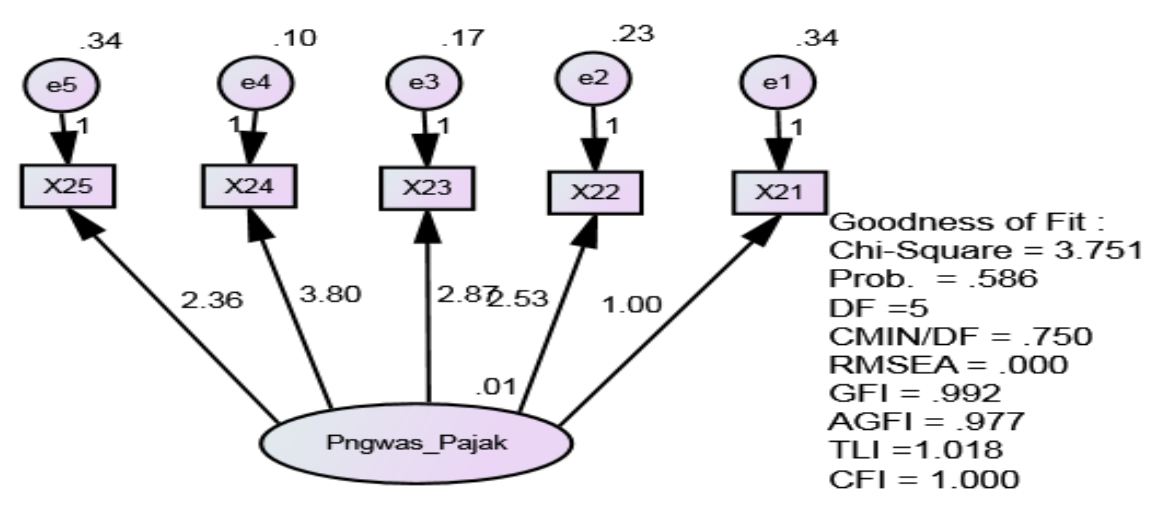

Gambar 2. Measurement ModelVariabel Pengawasan Pajak

Hasil uji kesesuaian model menghasilkan tingkat penerimaan yang baik. Nilaichisquare model ini sebesar 3.751 dengan probabilitas 0,586 > 0,05, danindeks GFI, AGFI, TLI, CLI, dan RMSEA berada dalam rentang nilai yang diharapkan. Selanjutnya, hasil uji confirmatory factor analysis atasvariabel Pemeriksaan Pajak tersaji pada Gambar3 berikut ini.

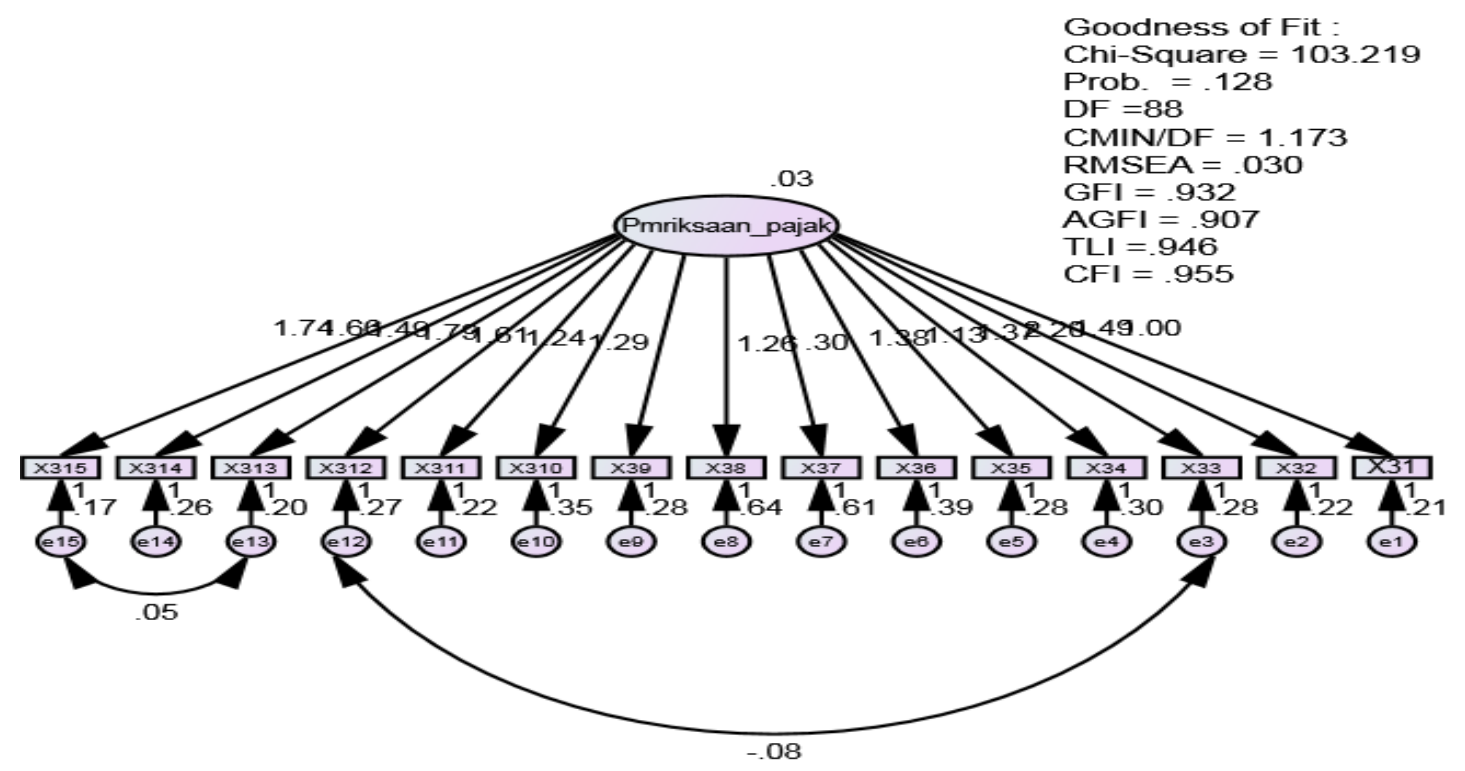

Gambar 3. Measurement ModelVariabel Pemeriksaan Pajak

Hasil uji kesesuaian model menghasilkan tingkat penerimaan yang baik. Nilai chisquare model ini sebesar 103.219 dengan probabilitas 0,128 > 0,05 danindeks GFI, AGFI, TLI, CLI, dan RMSEA berada dalam rentang nilai yang diharapkan. Selanjutnya, hasil uji confirmatory factor analysis atasvariabel Kepatuhan Pajak tersaji pada Gambar 4 berikut ini. 

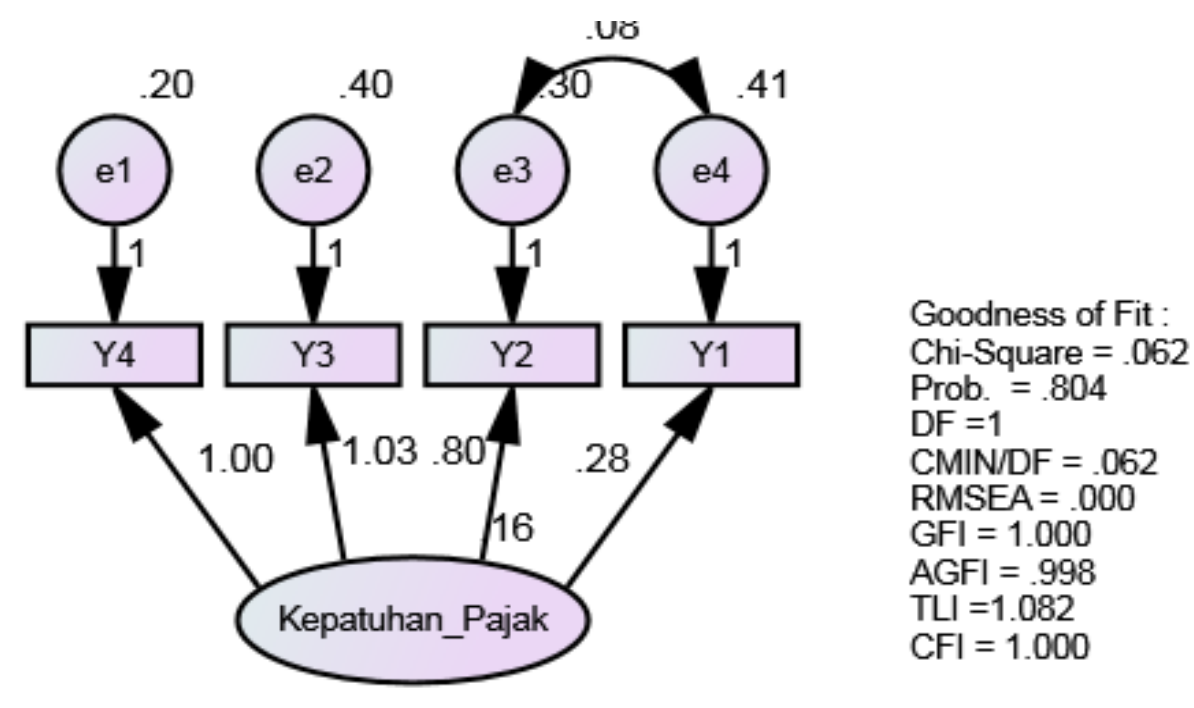

Gambar 4. Measurement ModelVariabel Kepatuhan Pajak

Hasil uji kesesuaian model menghasilkan tingkat penerimaan yang baik. Nilai chisquare model ini sebesar 0.062 dengan probabilitas 0,804 > 0,05 danindeks GFI, AGFI, TLI, CLI, dan RMSEA berada dalam rentang nilai yang diharapkan. Selanjutnya, hasil uji confirmatory factor analysis atasvariabel Penerimaan Negaratersaji pada Gambar5berikut ini.

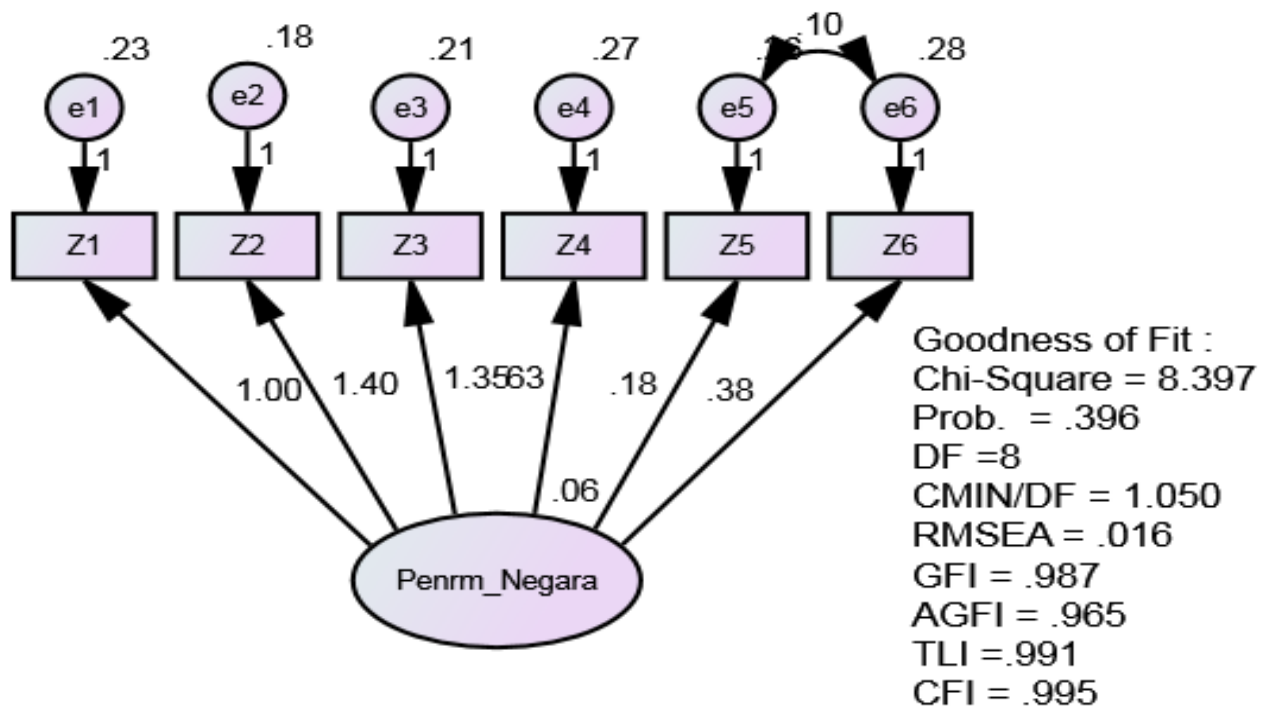

Gambar 5. Measurement ModelVariabel Penerimaan Negara

Hasil uji kesesuaian model menghasilkan tingkat penerimaan yang baik. Nilai chi-square model ini sebesar 8,397 dengan probabilitas 0,396 > 0,05 danindeks GFI, AGFI, TLI, CLI, dan RMSEA berada dalam rentang nilai yang diharapkan.

Hasil Uji Hipotesis.Hasil pengujian data menggunakanLisrelfull model ditampilkan pada Gambar 6 berikut ini. 


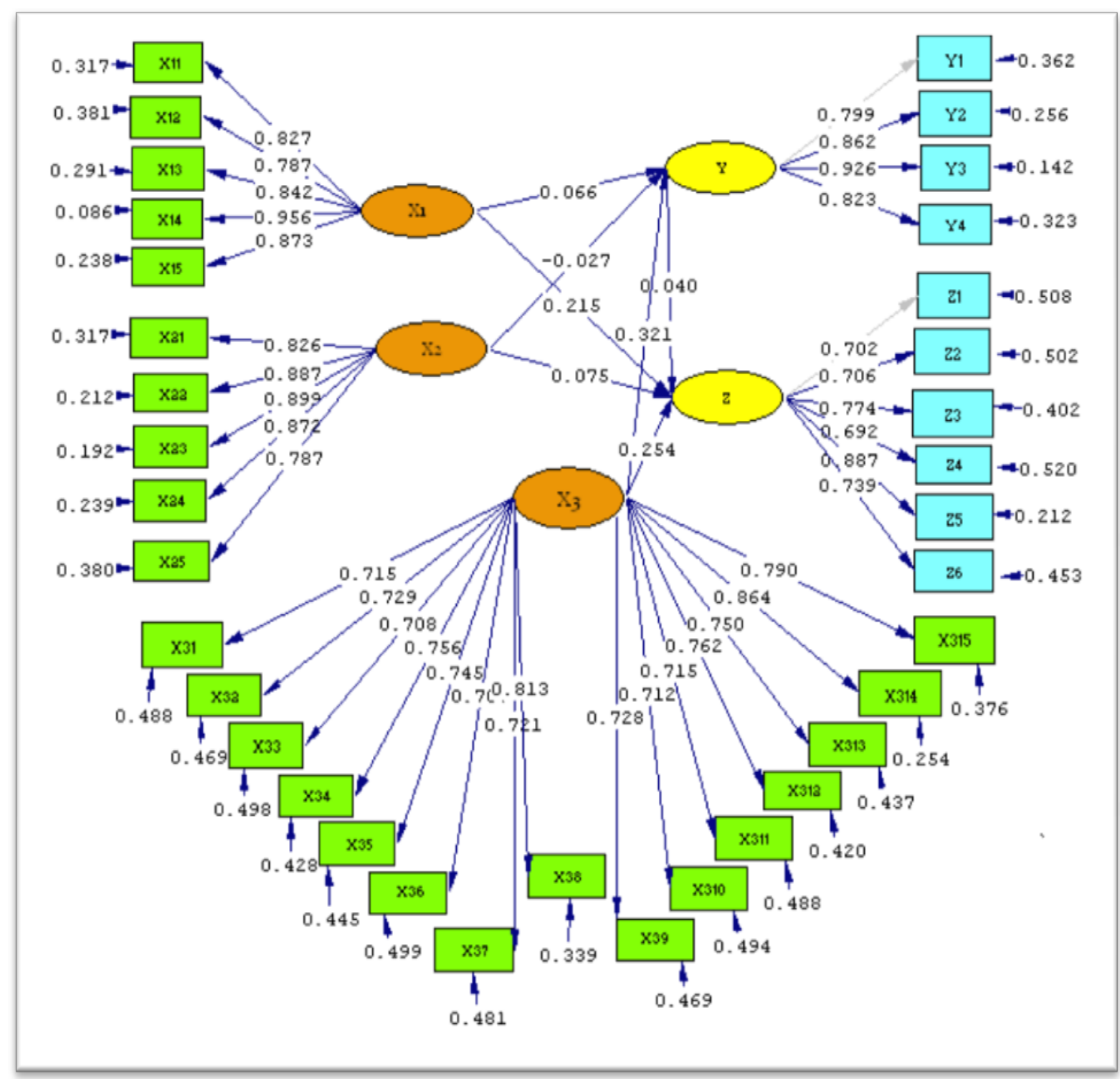

\section{Gambar 6. Structural Equation Model Setelah Modifikasi}

Berdasarkan Gambar 6 dapat dinyatakan bahwa hubungan antar konstruk memiliki nilai positif. Hubungan antara Konseling Pajak dengan kepatuhan pajak adalah 0,185 yang artinya adanya hubungan yang positif antara konseling pajak dengan kepatuhan pajak sebesar 0,185. Hubungan antara pengawasan pajak dengan kepatuhan pajak adalah -242 yang artinya adanya hubungan yang negatif antara pengawasan pajak dengan kepatuhan pajak sebesar -0.242. Hubungan antara pemeriksaan pajak dengan kepatuhan pajak adalah 0,744 yang artinya adanya hubungan yang positif antara pemeriksaan pajak dengan kepatuhan pajak sebesar 0,744. Selanjutnya hubungan antara kepatuhan pajak terhadap penerimaan Negara sebesar 0,694 Artinya adanya hubungan yang positif antara kepatuhan pajak terhadap penerimaan Negara sebesar 0,694. Pengujian selanjutnya adalah uji ModelGoodness of Fit. Hasil pengujian ini ditunjukkan pada Tabel 4 berikut ini. 
Amilin: Peran Konseling, Pengawasan dan Pemeriksaan oleh Petugas Pajak...

Tabel 4. Hasil Uji Goodness of Fit Overall Model Fit Model

\begin{tabular}{llll}
\hline \multicolumn{1}{c}{ Model } & Default Model & Cut off Value & Keterangan \\
\hline Chi-square (CMIN) & 582,919 & Didasarkan pada tes signifikansi diharapkan kecil \\
Probability Level (p) & 0,074 & $\geq 0,05$ & Baik \\
CMIN/DF & 1,09 & $\leq 2,00$ & Baik \\
GFI & 0,861 & $\geq 0,90$ & Mariginal \\
TLI & 0,947 & $\geq 0,90$ & Baik \\
CFI & 0,952 & $\geq 0,90$ & Baik \\
RMSEA & 0,021 & $\leq 0,08$ & Baik \\
\hline
\end{tabular}

Sumber: Hasil pengolahan data

Dari Tabel 4 dapat diketahui bahwa nilai default model lima alat ukur (Probability Level ( $\rho), C M I N / D F, T L I, C F I$, GFI dan RMSEA) semua menunjukkan angka yang cukup tinggi, yang mengindikasikan bahwa model sudah fit dengan data yang ada. Langkah berikutnya adalah pengujian hipotesis. Hasil uji regression weight dapat dilihat pada tabel di bawah ini.

Tabel 5. Estimasi Parameter Regression Weight Modification

\begin{tabular}{llrrrrr}
\hline & & Estimate & S.E. & C.R. & P & Label \\
\hline Kepth_pjk & $<---$ Kons_Pjk & .185 & .085 & 2.162 & 0.031 & par_26 \\
Kepth_pjk & $<---$ Pmrks_pjk & .744 & .185 & 4.016 & 0.000 & par_27 \\
Kepth_pjk & <--- Pengw_Pjk & -.242 & .194 & -1.251 & 0.211 & par_29 \\
pnrm_negara & $<---$ Kepth_pjk & .694 & .191 & 3.641 & 0,000 & par_28 \\
\hline
\end{tabular}

Sumber: Hasil pengolahan data

Hasil uji kausalitas menunjukkan bahwa nilai critical error tidak sama dengan nol, dan nilai $\rho<0,05$ sehingga ada hubungan yang nyata antara konseling pajak, pengawasan pajak, pemeriksaan pajak terhadap kepatuhan serta hubungan yang nyata antara kepatuhan pajak dengan penerimaan negara. Selanjutnya, dapat diketahui bahwa nilai probabilitas dari konseling pajak sebesar 0,031 yang lebih kecil dari 0,05 sehingga $\rho(0,031)<$ cut off value $(0,05)$, dengan tingkat signifikansi 5 persen, maka dapat disimpulkan bahwa variabel konseling pajak berpengaruh signifikan terhadap kepatuhan pajak. Dengan demikian, hipotesis pertama (Ha1) didukung.

Probabilitas variabel pengawasan pajak sebesar 0,211. Nilai ini lebih kecil dari 0,05 sehingga $\rho(0,211)<$ cut off value $(0,05)$ dengan tingkat signifikansi 5 persen, maka dapat disimpulkan bahwa variabel pengawasan pajak tidak berpengaruh signifikan terhadap kepatuhan pajak. Dengan demikian, hipotesis kedua (Ha2) tidak didukung. Selanjutnya, nilai probabilitas variabel pemeriksaan pajak sebesar 0,000. Nilaiini lebih kecil dari 0,05 sehingga nilai $\rho(0,000)<$ cut off value $(0,05)$, maka dapat disimpulkan bahwa variabel pemeriksaan pajak berpengaruh positif dan signifikan terhadapvariabel kepatuhan pajak. Dengan demikian, hipotesis ketiga (Ha3) didukung. Nilai probabilitas variabel kepatuhan pajak sebesar 0,000 . Nilai ini lebih kecil dari 0,05 sehingga $\rho(0,000)<$ cut off value $(0,05)$, dengan tingkat signifikansi 5 persen, sehingga dapat disimpulkan bahwa variabel kepatuhan pajak berpengaruh signifikan terhadap variabel penerimaan negara. Dengan demikian, hipotesis ketiga (Ha4) didukung. 
Selanjutnya, pada tabel 6berikut ini disajikan pengaruh tidak langsung dari masing-masing variabel eksogen yaitu konseling pajak, pengawasan pajak dan pemeriksaan pajak yang dimediasi oleh variabel kepatuhan pajak dengan nilai adalah sebagai berikut:

Tabel 6. Hasil pengujian indirect effect

\begin{tabular}{lrrrrr}
\hline & Pmrks_pjk & Pengw_Pjk & Kons_Pjk & Kepth_pjk & pnrm_negara \\
\hline Kepth_pjk & .000 & .000 & .000 & .000 & .000 \\
pnrm_negara & .517 & .168 & .128 & .000 & .000 \\
\hline
\end{tabular}

Sumber: Hasil pengolahan data

Keputusan untuk hipotesis kelima (Ha5). Dari data pada Tabel 5 dan Tabel 6 dapat diketahui bahwa nilai sebesar 0,128. Nilai tersebut diperoleh dari nilai pengaruh konseling pajak terhadap kepatuhan pajak sebesar 0.185, dan pengaruh kepatuhan pajak terhadap penerimaan negara sebesar 0,694. Dengan demikian total pengaruh dari variabel konseling pajak terhadap penerimaan negara melalui kepatuhan pajak adalah 0,185 x 0,694 =0,128. Dapat disimpulkan bahwa Hipotesis Kelima (Ha5)didukung. Dengan demikian, variabel konseling pajak dapat berpengaruh secara signifikan terhadap variabel penerimaan negara dengan kepatuhan sebagai variabel intervening.

Keputusan untuk hipotesis keenam (Ha6). Diperoleh nilai sebesar 0,168. Nilai tersebut diperoleh dari nilai pengaruh pengawasan pajak terhadap kepatuha pajak sebesar 0,242 dan pengaruh kepatuhan pajak terhadap penerimaan negara sebesar 0,694. Dengan demikian total pengaruh pada variabel pengawasan pajak terhadap penerimaan negara melalui kepatuhan pajak adalah $-0,242 \times 0,694=-0,168$. Dapat disimpulkan bahwa Hipotesis keenam (Ha6) dapat didukung, dimana variabel pengawasan dapat mempengaruhi penerimaan negara dengan kepatuhan sebagai variabel intervening.

Keputusan untuk hipotesis ketujuh (Ha7). Diperoleh nilai sebesar 0,128. Nilai tersebut diperoleh dari nilai pengaruh pemeriksaan pajak terhadap kepatuha pajak sebesar 0,744 dan pengaruh kepatuhan pajak terhadap penerimaan negara sebesar 0,694. Dengan demikian total pengaruh dari variabel pemeriksaan pajak terhadap penerimaan negara melalui kepatuhan pajak adalah 0,744 x 0,694 =0.517. Dapat disimpulkan bahwa Ha7 didukung, sehingga variabel pemeriksaan dapat mempengaruhi variabel penerimaan negara dengan kepatuhan sebagai variabel intervening.

Hasil uji hipotesis pertama menujukkan bahwa kegiatan konseling yang dilakukan oleh aparatur pajak kepada wajib pajak memberikan dampak signifikan terhadap kepatuhan wajib pajak dalam membayar pajak. Artinya, kegiatan konseling yang dilakukan secara tepat dan sesuai dengan kebutuhan wajb pajak dapat mendorong wajib pajak dalam mematuhi peraturan dan ketentuan perpajakan. Dalam praktik perpajakan sehari-hari, tidak semua wajib pajak sudah memahami secara detail mengenai peraturan perpajakan, oleh karena itu dengan adanya kegiatan konseling ini dapat memberikan manfaat bagi wajib pajak terutama dalam memahami aturan perpajakan, serta hak dan kewajiban wajib pajak sehingga mendorong wajib pajak untuk bertindak patuh terhadap peraturan. Hasil penelitian ini konsisten dengan beberapa penelitian terdahulu yang dilakukan oleh Fahluzy, Fahmi dan Agustina (2014)dan Nugroho dan Zulaikha (2012). Selain itu, temuan ini juga selaras dengan Peraturan Dirjen PajakNomor170/PJ/2007 tanggal 11 Desember 2007 bahwaKonseling Pajakmerupakan sarana yang disediakan bagi Wajib Pajak untuk melakukan klarifikasi terhadapdata yang tercantum dalam Surat Himbauan. 
Hasil uji hipotesis kedua menujukkan bahwa kegiatan pegawasanyang dilakukan oleh aparatur pajak terhadap wajib pajak tidak memberikan dampak signifikan terhadap kepatuhan wajib pajak dalam membayar pajak. Hasil penelitian ini tidak konsisten dengan hasil penelitian yang dilakukan oleh Handayani, et al. (2012), Kusbandiyahet al. (2013) dan Permadi (2013). Tidak konsistennya temuan hasil pengujian hipotesis ini diduga karena kegiatan pengawasan yang dilakukan oleh aparatur pajak lebih menekankan pada aspek administratif. Apabila kegiatan pengawasan dibarengi dengan pendekatan persuasif yang didukung dengan komunikasi yang efektif diduga dapat mendorong kepatuhan wajib pajak.Hal ini dipertegas oleh Surat Edaran Ditjen Pajak Nomor SE-05/PJ.07/2004 tanggal 16 Juni 2004 yang menyatakan bahwa salah satu bentuk pengawasan terhadap wajib pajak adalah aktivitas himbauan yaitu kegiatan persuasif yang dilakukan dengan cara mengirimkan surat yang memberitahukan kondisi pelaksanaan kewajiban perpajakan bagi wajib pajak terpilih.

Hasil uji hipotesis ketiga menujukkan bahwa pemeriksaan pajakyang dilakukan oleh aparatur pajak terhadap wajib pajak berdampak signifikan terhadap kepatuhan wajib pajak dalam membayar pajak. Artinya, dengan adanya pemeriksaan wajib pajak cenderung lebih berhati-hati dalam menghitung kewajiban perpajakannya dan melaporkan kewajiban perpajakannya sesuai dengan waktu yang telah ditentukan sehingga terhindar dari sanksi perpajakan. Temuan ini konsisten dengan hasil penelitian Widayati dan Nurlis (2010), Nugroho dan Zulaikha (2012), dan Setyonugroho dan Sarjono (2013). Temuan ini selaras dengan Undang-undangNomor28Tahun 2007 Pasal 29 dan Peraturan Menteri Keuangan Nomor: 17/PMK.03/2013 tanggal 7 Januari 2013 bahwa pemeriksaan pajak dilakukan melalui serangkaian kegiatan menghimpun dan mengolah data, keterangan dan/atau bukti yang dilaksanakan secara objektif dan profesional berdasarkansuatu standar pemeriksaan untuk menguji kepatuhan pemenuhan kewajiban perpajakan dan/atau untuk tujuan lain dalam rangka melaksanakan ketentuan peraturan perundang-undangan perpajakan.

Hasil uji hipotesis keempat menujukkan bahwa kepatuhan wajib pajakmemberikan dampak positif dan signifikan terhadap penerimaan negara dari sektor pajak. Artinya, apabila wajib pajak mematuhi semua undang-undang dan peraturan perpajakan terkait, maka pelaporan dan pembayaran pajak dilakukan secara obyektif dan transparan sehingga secara otomatis dapat meningkatkan pendapatan negara dari sektor pajak. Hasil temuan ini konsisten dengan hasil penelitian yang dilakukan oleh Rantung dan Adi (2009), Hardiningsih dan Yulianawati (2011), dan Norsain dan Abu Yasid (2013). Kepatuhan pajak diharapkan lebih merujuk pada kepatuhan sukarela yaitu mencakup tingkatan kesadaran untuk tunduk kepada peraturan perpajakan yang berlaku tanpa disertai dengan aktivitas tindakan dari otoritas pajak, serta konsisten dalam menjalankan sesuatu yang tersirat dari aturan pajak tersebut (Devano dan Rahayu, 2010:56).

Hasil uji hipotesis kelima menujukkan bahwa variabel kepatuhan wajib pajak dapat memediasi pengaruh konseling terhadap penerimaan pajak. Dengan kata lain, penerimaan pajak dapat meningkat apabila wajib pajak patuh melaksanakan kewajibannya dalam membayar pajak. Untuk membuat wajib pajak patuh perlu memberikan pemahaman yang memadai kepada para wajib pajak. Agar wajib pajak dapat memahami hak dan kewajibannya, perlu dilakukan kegiatan konseling yang efektif dan efisien. Hasil penelitian ini konsisten dengan penelitian-penelitian sebelumnya yang dilakukan oleh Fahluzy, Fahmi dan Ortega et al. (2013), Nugroho dan Zulaikha (2012), dan Agustina (2014), Rantung dan Adi (2009), Hardiningsih dan Yulianawati (2011), dan Norsain dan Abu Yasid (2013). 
Hasil uji hipotesis keenam menujukkan bahwa variabel kepatuhan wajib pajak dapat memediasi pengaruh pengawasan terhadap penerimaan pajak. Berbeda dengan hasil pengujian hiptesis kedua yang menunjukkan bukti empiris bahwa pengawasan tidak dapat mempengaruhi secara langsung terhadap kepatuhan wajib pajak. Namun, ketika kepatuhan wajib pajak diuji sebagai variabel intervening maka mampu memediasi pengaruh pengawasan terhadap penerimaan pajak. Hasil penelitian ini tidak konsisten dengan hasil penelitian yang dilakukan oleh Handayani, et al. (2012), Kusbandiyah et al. (2013) dan Permadi (2013), namun konsisten dengan sebagian hasil penelitian yang dilakukan oleh Rantung dan Adi (2009), Hardiningsih dan Yulianawati (2011), dan Norsain dan Abu Yasid (2013). Berkenaan dengan temuan ini, perlu pendekatan pengawasan yang lebih baik pada era terbuka saat ini.

Hasil uji hipotesis ketujuh menujukkan bahwa variabel kepatuhan wajib pajak dapat memediasi pengaruh pemeriksaan terhadap penerimaan pajak. Hasil penelitian ini konsisten dengan hasil penelitian Widayati dan Nurlis (2010), Nugroho dan Zulaikha (2012), Setyonugroho dan Sarjono (2013), Rantung dan Adi (2009), Hardiningsih dan Yulianawati (2011), dan Norsain dan Abu Yasid (2013). Temuan ini menunjukkan bahwa kepatuhan wajib pajak merupakan faktor penting dalam mendorong efektifitas kegiatan pemeriksaan sehingga dapat meningkatkan penerimaan pajak. Temuan-temuan penelitian ini secara umum relevan dengan teori kemakmuran. Teori kemakmuran yang kemukakan oleh Adam Smith dalam Becker (2007: 17) menyatakan bahwa tingkat kemakmuran ditentukan oleh kemampuan manusia sebagai salah satu faktor produksi dalam sebuah negara. Manusia yang berakal dan berbudaya tentu menghendaki dalam kehidupannya ingin makmur dan sejahtera.

\section{PENUTUP}

Kesimpulan. Hasil penelitian ini diperoleh beberapa kesimpulan sebagai berikut: Pertama, kegiatan konseling yang dilakukan oleh aparatur pajak kepada wajib pajak memberikan dampak signifikan terhadap kepatuhan wajib pajak dalam membayar pajak. Kedua, kegiatan pegawasan yang dilakukan oleh aparatur pajak terhadap wajib pajak tidak memberikan dampak signifikan terhadap kepatuhan wajib pajak dalam membayar pajak. Ketiga, pemeriksaan pajak yang dilakukan oleh aparatur pajak berdampak signifikan terhadap kepatuhan wajib pajak dalam membayar pajak. Keempat, kepatuhan wajib pajak memberikan dampak positif dan signifikan terhadap penerimaan negara dari sektor pajak. Kelima, konseling pajak dapat meningkatkan penerimaan negara melalui kepatuhan wajib pajak sebagai variabel intervening.Keenam, pengawasan dapat meningkatkan penerimaan negara melalui kepatuhan wajib pajak sebagai variabel intervening.Terakhir, pemeriksaan pajak dapat meningkatkan penerimaan negara melalui kepatuhan sebagai variabel intervening.

Penelitian ini dihadapkan pada beberapa keterbatasan. Pertama, metode pemilihan sampel menggunakan metode convenience sampling sehingga memiliki keterbatasan perihal keterwakilan responden dalam populasi, dengan demikian kekuatan generalisasinya rendah. Kedua, hasil pengujian variabel pegawasan tidak berpengaruh terhadap kepatuhan wajib pajak dalam membayar pajak. Temuan ini tidak konsisten dengan hasil penelitian sebelumnya. Diduga, pengawasan yang dilakukan belum berjalan efektif. 
Saran. Penelitian sejenis di masa mendatang diharapkan dapat menyajikan hasil penelitian yang lebih berkualitas dibanding penelitian ini dengan memperhatikan beberapa saran berikut ini. Pertama, sebaiknya menggunakan metode pemilihan sampel lain yang memiliki probalilitas keterwakilannya lebih presisi, misalnya dengan menggunakan metode stratifed random sampling. Kedua, agar pengawasan berjalan efektif, Direktorat Jenderal Pajak perlu melakukan evaluasi melalui pendekatan pengawasan yang lebih baik. Pendekatan pengawasan yang dilakukan oleh aparatur pajak perlu dilakukan dengan pendekatan persuasif.

\section{DAFTAR RUJUKAN}

Andreoni, J., Erard, B., and Feinstein, J. (1998) Tax Compliance. Journal of Economic Literature.

Becker, Gary. (2007) The Economic Approach to Human Behavior. 13 ${ }^{\text {th }}$ Edition. Pearson Prentice Hall.

Brotodihardjo, R.S.(1998) Pengantar Ilmu Hukum Pajak, Bandung: PT.Refika Aditama, cetakan ke-19.

Devano, S dan Siti Rahayu. (2010) Perpajakan: Konsep, Teori, dan Isu, Kencana, Jakarta.

Fahluzy, S. Fahmi dan L. Agustina. (2014) Faktor-Faktor yang Mempengaruhi Kepatuhan Membayar Pajak UMKM di Kabupaten Kendal. Accounting Analysis Journal,Vol. 3.

Ghozali, Imam. (2011) Aplikasi Analisis Multivariate Dengan Program IBM SPSS 19, Edisi 5. Badan Penerbit Universitas Diponegoro. Semarang.

Handayani, Sapti Wuri et al. (2012) Faktor-Faktor yang Mempengaruhi Kepatuhan Membayar Pajak Wajib Pajak Orang Pribadi yang Melakukan Pekerjaan Bebas. Proceeding Simposium Nasional Akuntansi ke-15.

Hardiningsih, Pancawati dan Nila Yulianawati. (2011) Faktor-Faktor yang Mempengaruhi Penerimaan Pajak. Jurnal Dinamika Keuangan dan Perbankan, Vol. 3 (1).

Kusbandiyah, Ani dan Iwan Fakhruddin. (2013) The Factors Influence Willingness to Pay Tax: An Empirical Study on Employee Muhammadiyah University Purwokerto, Indonesia. Proceeding of International Conference on Business and Mangement.

Kirchler, E., Hoelzl E. (2006) Modelling Taxpayers behavior as a function of Internaction Between Tax Authorities and Taxpayers In H. Elffers, P. Verboon and W. Huisman (Ed), Managing and Maintaining Compliance. Boom Legal Publishers.

Lymer A. and Oats L. (2009) Taxation: Policy and Practice. 16th ed. Birmingham: Fiscal Publications.

Loo, E. C., McKerchar, Margaret, Hansford, Ann. (2010) Finding on the Impact of Self Assesment on the Compliance Behavior of Individual Tax Payer in Malaysia: A Case Study Approach. Journal of Australia Taxation.

Nugroho, Rahman Adi dan Zulaikha. (2012) Faktor-Faktor yang Mempengaruhi Kepatuhan Membayar Pajak Dengan Kesadaran Membayar Pajak Sebagai Variabel Intervening (Studi Kasus Wajib Pajak Orang Pribadi yang Melakukan Pekerjaan Bebas yang Terdaftar di KPP Pratama Semarang Tengah Satu). Diponegoro Journal of Accounting, Vol. 1 (2).

Norsain dan Abu Yasid. (2014) Pengaruh Perubahan Tarif, Kepatuhan Membayar Pajak, dan Sosialisasi PP Nomor 46 Tahun 2013 Terhadap Penerimaan NegaraJurnal "Performance” Bisnis \& Akuntansi Volume IV, No.2. 
Ortega, Daniel, et. all. (2013) Reciprocity and Willingness to Pay Taxes:Evidence from a Survey Experiment in Latin America. Journal of Centro de Investigacion Y Accion Social (CIAS) No. 2.

Peraturan Menteri Keuangan PMK Nomor 17/PMK.03/2013 tentang Tata Cara Pemeriksaan.

Peraturan Dirjen Pajak Nomor 170/PJ/2007 tanggal 11 Desember 2007 tentang Tata Cara Pelaksanaan Konseling Terhadap Wajib Pajak Sebagai Tindak Lanjut Surat Himbauan.

Permadi, Tedi et al.(2013) Studi Kepatuhan Membayar Pajak Pada Wajib Pajak Orang Pribadi Yang Melakukan Pekerjaan Bebas (Kasus Pada Kpp Pratama Tampan Pekanbaru). Jurnal Ekonomi Universitas Riau Vol. 21 No. 2.

Priantara, Diaz.(2010). Pemeriksaan Pajak dan Penyidikan Pajak. Jakarta: Djambatan. Edisi Pertama.

Rantung, Tatiana Vanessa dan Priyo Hari Adi. (2009).Dampak Program Sunset Policy Terhadap Faktor-Faktor yang Mempengaruhi Kemauan Membayar Pajak dan Pengaruhnya terhadap Penerimaan Pajak (Studi pada Wajib Pajak Orang Pribadi Pelaku Usaha di Wilayah KPP Pratama Salatiga). Simposium Nasional Perpajakan II.

Setyonugroho, H. dan B. Sardjono. (2013). Factors Affecting Willingness To Pay Taxes On Individual Taxpayers At Pratama Surabaya Tegalsari Tax Office. The Indonesian Accounting Review Vol. 3 Nomor 1.

SuratEdaranDirjenPajak Nomor SE-05/PJ.07/2004 tanggal 16 Juni 2004 tentang Aktivitas Pendukung Pemeriksaan.

Undang-undangNomor28Tahun 2007 Perubahan Ketiga Atas Undang-Undang Nomor 6 Tahun 1983 Tentang Ketentuan dan Tata Cara Perpajakan. 